\title{
Towards a global land subsidence map
}

\author{
G. Erkens ${ }^{1,2}$ and E. H. Sutanudjaja ${ }^{1,2}$ \\ ${ }^{1}$ Deltares Research Institute, Utrecht, the Netherlands \\ ${ }^{2}$ Utrecht University, Utrecht, the Netherlands \\ Correspondence to: G. Erkens (gilles.erkens@ deltares.nl)
}

Published: 12 November 2015

\begin{abstract}
Land subsidence is a global problem, but a global land subsidence map is not available yet. Such map is crucial to raise global awareness of land subsidence, as land subsidence causes extensive damage (probably in the order of billions of dollars annually). With the global land subsidence map relative sea level rise predictions may be improved, contributing to global flood risk calculations.

In this paper, we discuss the approach and progress we have made so far in making a global land subsidence map. Initial results will be presented and discussed, and we give an outlook on the work needed to derive a global land subsidence map.
\end{abstract}

\section{Introduction}

Although its impact on flood risk is locally outranging the impact of absolute sea level rise, over the last decades land subsidence retrieved much less attention in terms of research. One of the reasons for this is the unknown extent of land subsidence around the world, in contrast to absolute sea level rise. For the latter, there are models that predict global absolute sea level rise (Church et al., 2013). For land subsidence there are many examples around the world, but a comprehensive picture of the global extent is currently unavailable. This originates from the heterogeneity of the land subsidence signal: an array of potential drivers and the heterogeneous subsurface hydrology and geology, makes land subsidence mainly a local phenomenon on a global scale.

A map showing the extent of land subsidence around the world, the global land subsidence map, would be very useful. It would raise awareness among scientist and policymakers alike. The land subsidence rates could be used - together with regional absolute sea level rise predictions - to estimate relative sea level rise in coastal areas. This serves as input for flood risk calculations. Lastly, a global land subsidence map would not only locate current land subsidence hotspots but also help to identify future sinking areas under predicted socio-economic development scenarios.
The maps that come close to a global land subsidence map are those based on a collection of globally spread case studies. However, these have two major limitations:

i. They are static and show the current land subsidence rates, but not necessarily at a single moment in time. They also have no predictive power.

ii. They are biased towards well-studied areas. Large cities or classic study sites in western countries show up most prominently.

Considering these limitations, we set out to produce a global land subsidence map that is derived from numerical model calculations. In this way, we are able to introduce a temporal component showing both historical and predicted future land subsidence under different development scenarios.

In this paper, we discuss the approach and progress we have made so far. Initial results will be presented and discussed, and we give an outlook on the work needed to derive a global land subsidence map.

\section{The approach}

Land subsidence is caused my many different drivers, both natural and anthropogenic-induced. Ideally, a global land subsidence map would cover all known drivers, but for sake of simplicity, in first instance we restricted ourselves 


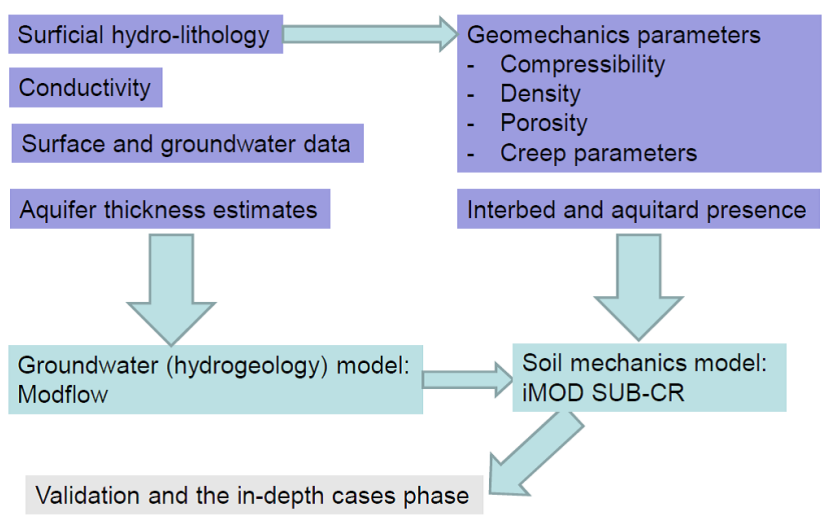

Figure 1. The proposed model suite to derive a global land subsidence map consists of three coupled models: the surface water model, the ground water model and a soil mechanics model.

to one driver. One of the most prominent causes for land subsidence is aquifer compaction as a result of excessive groundwater extraction for domestic, agricultural and industrial use (Galloway and Burbey, 2011). For instance, the Vietnamese Mekong Delta sinks on average $1.6 \mathrm{~cm} \mathrm{yr}^{-1}$, attributed to groundwater extraction (Erban et al., 2014). Crucially, in many coastal mega-cities, land subsidence is accelerated by ongoing urbanization and related increased demands for (ground) water. In Jakarta land subsidence is up to $20 \mathrm{~cm} \mathrm{yr}^{-1}$ (Abidin et al., 2008). With ongoing economic development in the near future the expectation is that groundwater abstraction and, consequently, land subsidence rates, will accelerate and areas affected will expand as well as. Therefore, in this paper, we chose to focus on aquifer abstraction induced land subsidence and present our numerical approach on constructing a global land subsidence map.

Figure 1 illustrates different the model components used in this study. The integrated global hydrological and water resources model, PCR-GLOBWB (Van Beek et al., 2011; Sutanudjaja et al., 2015; Van Beek, 2008; Van Beek and Bierkens, 2009), serves as the starting point. The model is fed by global meteorological forcing data (i.e. precipitation, temperature and reference potential evaporation) and parameterized based on only global datasets (for an extensive list, see e.g. Sutanudjaja et al., 2011). PCR-GLOBWB simulates daily river discharge and groundwater recharge, as well as surface water and groundwater abstraction rates. The latter are estimated internally within the model based on the simulation of their availabilities and water demands for irrigation and other sectors (De Graaf et al., 2014; Wada et al., 2014). The daily output of PCR-GLOBWB would then be aggregated to the monthly resolution and used to force the MODFLOW groundwater model (McDonald and Harbaugh, 1988; Sutanudjaja et al., 2011, 2014) resolving spatio-temporal groundwater head dynamics, incorporating the simulated groundwater abstraction of PCR-GLOBWB. Subsequently, the simulated monthly groundwater head changes are fed into a land subsidence module, iMOD-SUB-CR (Bakr, 2015), which is an extension of the subsidence and aquifer-system compaction package (SUB-WT) of MODFLOW (Leake and Galloway, 2007). For this study all aforementioned models are simulated at the spatial resolution of 5 arc minutes (approximately $10 \mathrm{~km}$ at the equator).

\section{First results}

In this study we perform all aforementioned model simulations for the period 1958-2010. Our results are focused on the simulation results of PCR-GLOBWB that are fed in the MODFLOW model, particularly the rates of groundwater depletion, i.e. the abstraction of groundwater stores that are not being replenished by groundwater recharge. More specifically, we present and summarize the groundwater depletion rates in urban areas.

\subsection{First attempt: depletion in urban area missed}

Figure 2 shows first results for the island of Java, Indonesia. This is an area that is well known for its extensive land subsidence as a result ground water extraction. The map shows the depletion of ground water as calculated by the PCRGLOBWB hydrology model. Most of the areas that show depletion are irrigation areas, where the model suggests that groundwater is excessively used. Large urban areas, such as Jakarta, with well-known depletion of groundwater and related land subsidence, are completely missed.

This misconception is attributed to the previous assumption in the PCR-GLOBWB model that simplifies that the fraction of water demands that is satisfied by groundwater resource $\left(\mathrm{GW}_{\text {frac }}\right)$ as a ratio between simulated baseflow and river discharge. Agricultural irrigation results in a high water demand, and because the river discharge in those areas is dominated by baseflow, the model assumes the use of groundwater. While in the urban area of Jakarta where river flows are not baseflow dominant, water demands are lower and as a result, surface water availability as simulated for Jakarta is sufficient for the domestic and industrial water demand. However, in reality, the urban areas in Java rely on ground water as a clean and reliable source of water. In turn, it is foremost surface water that is used for irrigation in Java.

\subsection{Second attempt: including water resources uses}

To improve the model, we included (global) databases on the relative contribution of ground water and surface water to the total water usage, for both urban agglomerations (McDonald et al., 2014: Dataset of water infrastructure) and agricultural areas (Siebert et al., 2010: Groundwater use for irrigation). Figure 3 shows the result of the second attempt in which the contribution of actual groundwater and surface water is included. The fraction of water demands that is satisfied by groundwater resource $\left(\mathrm{GW}_{\text {frac }}\right)$ is prescribed based on the 


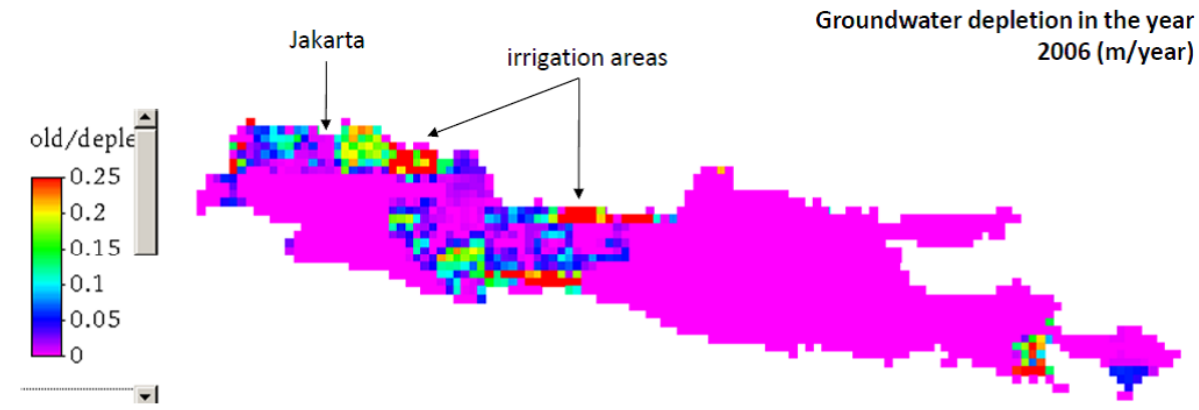

Figure 2. Screen shot of initial depletion $\left(\mathrm{m} \mathrm{yr}^{-1}\right)$ results as calculated by the global hydrology model for the island of Java, Indonesia. It shows the depletion of the groundwater as a result of abstraction for irrigation of agricultural areas, but misses known depleted urban areas, such as Jakarta.

Table 1. Calculated depletion ( $\mathrm{m} \mathrm{yr}^{-1}$ for the period 2000-2010) for a selection of cities that are known to subside.

\begin{tabular}{llc}
\hline Country & City & Depletion $\left(\mathrm{m} \mathrm{yr}^{-1}\right)$ \\
\hline United States & San Jose & 3.27 \\
Mexico & Mexico City & 1.30 \\
United States & Tucson & 1.29 \\
United States & San Francisco & 1.25 \\
Iran & Tehran & 1.23 \\
United States & Sacramento & 1.18 \\
\hline
\end{tabular}

aforementioned inventories. This outcome resembles much closer the expected outcome: dominant depletion in the urban areas.

In Fig. 4, the results of the same model run for the South China Sea area are depicted (depletion in $\mathrm{m} \mathrm{yr}^{-1}$ ). This matches known areas of subsidence and groundwater extraction, such as the western half of Taiwan, the cities of Hong Kong, Shanghai, Qingdao and Beijing. It also captured the North China Plain, which is an agricultural area with strongly depleted aquifers. These results give confidence in the validity of the model.

\subsection{A global city database of groundwater abstractions and discussion}

Based on the model calculations, we are now able provide depletion per year for different urban areas. Table 1 lists some examples of calculated depletion rates for a selected number of cities for the period 2000-2010.

Most of the cities that are known to have depletion of the aquifers are found on the list. Some cities, such as Ho-ChiMinh City (Vietnam) or Albuquerque (New Mexico, USA) are, however, missed. One of the possible explanations for this is the unknown contribution of irrigation. This may be overestimated in urban areas, which suffer from land surface sealing as a result of building. The rates as calculated by the model are on the lower end of reported depletion rates. This may be the consequence of the scale that we use: depletion rates are averaged over a $10 \times 10 \mathrm{~km}$ gridcel. Groundwater extraction and depletion, specifically for industrial sites, may however be much more local than that. Another interesting outcome is the prominent position of the city of San Jose (USA) with $3.27 \mathrm{~m} \mathrm{yr}^{-1}$ depletion calculated for the 2000 2010 period (Table 1). In reality, depletion in the San Jose area has essentially stopped after dramatic subsidence forced the local government to reduce groundwater abstraction (Ingebritsen and Jones, 1999). Surface water is now being imported from elsewhere and the imported water is partly used for recharging the aquifer systems. The model however, still calculates the consumption of ground water in San Jose, as in the model local surface water availability is insufficient.

\section{Towards a global land subsidence map}

The PCR-GLOBWB outcomes will be used to force a twolayer global Modflow model, consisting of an upper unit with low permeability and a deeper confined aquifer system. The groundwater model will yield hydraulic heads. A decrease in hydraulic head will not automatically imply that subsidence will occur. If the deposits consist of sand, or are (over)consolidated, the hydraulic pressure decrease and effective stress increase will not lead to inelastic volume reduction. There is enough global information on the surface geology (e.g. Dürr, et al., 2005) to be able to focus only on those areas that are susceptible to subside. The required subsurface information to parameterize the geotechnical model is however unavailable on a global scale at this time, but will be approached by using different scenarios of subsurface buildup.

The outcomes will be compared to measured or modeled land level lowering in well-known case study areas, such as Jakarta and the Vietnamese Mekong Delta. The final map will include also future land subsidence rates under different development scenarios for the entire earth, and includes a sensitivity test for different subsurface build-up. The entire map will be used as input for a global flood risk model. This 


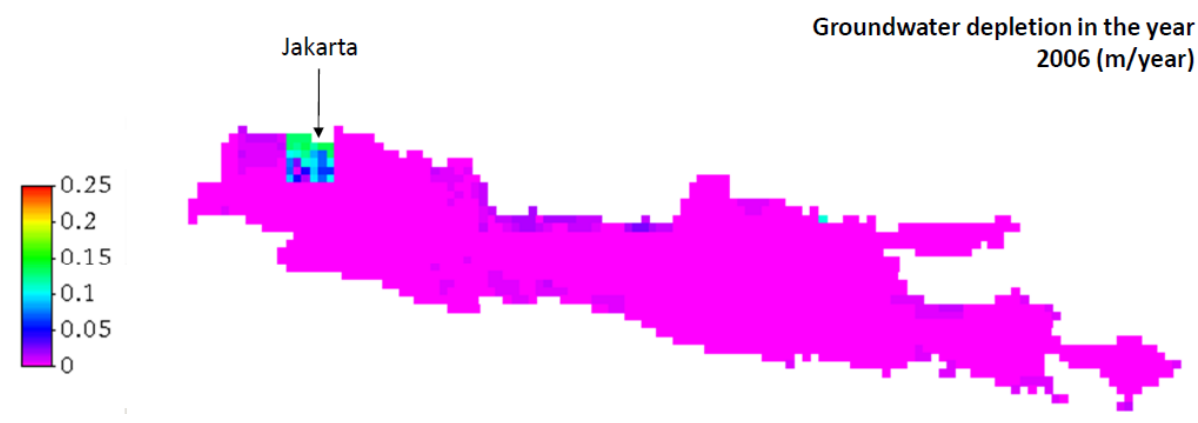

Figure 3. Screen shot of revised depletion $\left(\mathrm{m} \mathrm{yr}^{-1}\right)$ results as calculated by the global hydrology model for the island of Java, Indonesia. It shows the depletion of the groundwater as a result of ground water abstraction in the urban area of Jakarta. The calculated depletion in the irrigation areas is now minor.

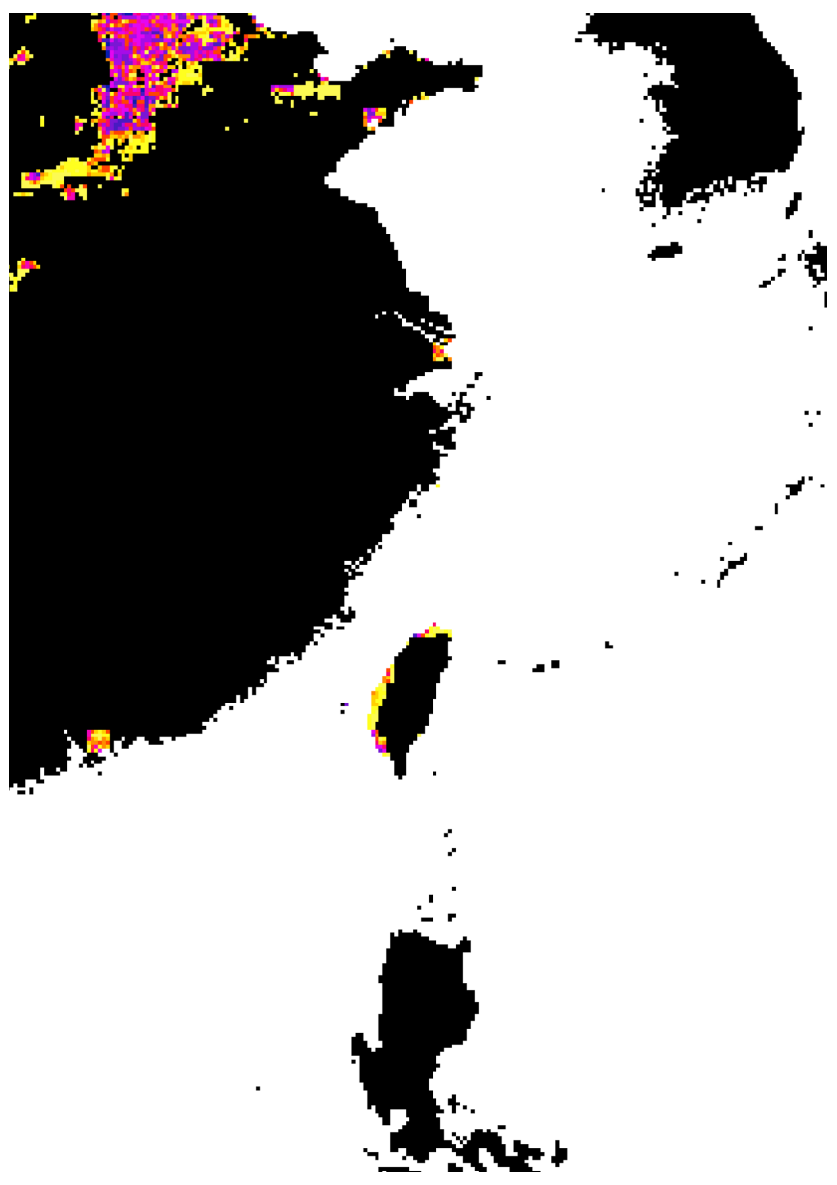

Figure 4. Screen shot of depletion $\left(\mathrm{m} \mathrm{yr}^{-1}\right)$ results as calculated by the global hydrology model for the east coast of China and Taiwan. The cities of Hong Kong, Shanghai, Qingdao and Beijing can be recognised. The large area in the north is the North China Plain, which is an agricultural area.

will be done within the concept of a dynamic DEM (digital elevation model). Within this concept, the currently available height information (DEM) for a certain area is updated with the cumulative subsidence (or uplift) over a certain period of time. The predicted global land subsidence effects will be included in flood hazard and storm surge assessments within a global flood risk model.

Acknowledgements. The authors thank their colleagues Marijn Kuijper (Deltares Research Institute), Hessel Winsemius (Deltares Research Institute), Inge de Graaf (Utrecht University) and Marc Bierkens (Utrecht University, Deltares Research Institute) for data, support and discussion. This paper is a part of the World Resources Institute project Flood Risk and Intervention Assessment for Global Cities funded by the Netherlands Ministry of Infrastructure and Environment and the Netherlands Ministry of Foreign Affairs.

\section{References}

Abidin, H. Z., Andreas, H., Djaja, R., Darmawan, D., and Gamal, M.: Land subsidence characteristics of Jakarta between 1997 and 2005, as estimated using GPS surveys, GPS Solut., 12, 23-32, 2008.

Bakr, M.: Influence of Groundwater Management on Land Subsidence in Deltas A Case Study of Jakarta (Indonesia), Water Resour. Manag., 29, 1541-1555, doi:10.1007/s11269-014-0893-7, 2015.

Church, J. A., Clark, P. U., Cazenave, A., Gregory, J. M., Jevrejeva, S., Levermann, A., Merrifield, M. A., Milne, G. A., Nerem, R. S., Nunn, P. D., Payne, A. J., Pfeffer, W. T., Stammer, D., and Unnikrishnan, A. S.: Sea Level Change, in: Climate Change 2013: The Physical Science Basis. Contribution of Working Group I to the Fifth Assessment Report of the Intergovernmental Panel on Climate Change, edited by: Stocker, T. F., Qin, D., Plattner, G.K., Tignor, M., Allen, S. K., Boschung, J., Nauels, A., Xia, Y., Bex, V., and Midgley, P. M., Cambridge University Press, Cambridge, United Kingdom and New York, NY, USA, 2013.

De Graaf, I. E. M., van Beek, L. P. H., Wada, Y., and Bierkens, M. F. P.: Dynamic attribution of global water demand to surface water and groundwater resources: Effects of abstractions and return flows on river discharges, Adv. Water Resour., 64, 21-33, 2014.

Dürr, H. H., Meybeck, M., and Dürr, S. H.: Lithologic composition of the Earth's continental surfaces derived from a new digital map emphasizing riverine material transfer, Global Biogeochem. Cy., 19, GB4S10, doi:10.1029/2005GB002515, 2005. 
Erban, L. E., Gorelick, S. M., and Zebker, H. A.: Groundwater extraction, land subsidence, and sea-level rise in the Mekong Delta, Vietnam, Environ. Res. Lett., 9, 084010, doi:10.1088/17489326/9/8/084010, 2014.

Galloway, D. L. and Burbey, T. J.: Review: Regional land subsidence accompanying groundwater extraction, Hydrogeol. J., 19, 1459-1486, 2011.

Ingebritsen, S. E. and Jones, D. R.: Santa Clara Valley, California A case of arrested subsidence, in: Land Subsidence in the United States by Galloway, D., Jones, D. R., and Ingebritsen, S. E., U.S. Geological Survey Circular 1182, 177 pp., 15-22, 1999.

Leake, S. A. and Galloway, D. L.: MODFLOW ground-water model - User guide to the Subsidence and Aquifer-System Compaction Package (SUB-WT) for water-table aquifers, U.S. Geological Survey, Techniques and Methods, 6-A23, 42 pp., 2007.

McDonald, M. G. and Harbaugh, A. W.: A modular threedimensional finite-difference ground-water flow model: Techniques of Water-Resources Investigations of the United States Geological Survey, Book 6, Chapter A1, 586 pp., 1988.

McDonald, R. I., Weber, K., Padowski, J., Flörke, M., Schneider, C., Green, P. A., Gleeson, T., Eckman, S., Lehner, B., Balk, D., Boucher, T., Grill, G., and Montgomery, M.: Water on an urban planet: Urbanization and the reach of urban water infrastructure, Global Environ. Chang., 27, 96-105, 2014.

Siebert, S., Burke, J., Faures, J. M., Frenken, K., Hoogeveen, J., Döll, P., and Portmann, F. T.: Groundwater use for irrigation - a global inventory, Hydrol. Earth Syst. Sci., 14, 1863-1880, doi:10.5194/hess-14-1863-2010, 2010.

Sutanudjaja, E. H., van Beek, L. P. H., de Jong, S. M., van Geer, F. C., and Bierkens, M. F. P.: Large-scale groundwater modeling using global datasets: a test case for the Rhine-Meuse basin, Hydrol. Earth Syst. Sci., 15, 2913-2935, doi:10.5194/hess-152913-2011, 2011.
Sutanudjaja, E. H., van Beek, L. P. H., de Jong, S. M., van Geer, F. C., and Bierkens, M. F. P.: Calibrating a large-extent highresolution coupled groundwater-land surface model using soil moisture and discharge data, Water Resour. Res., 50, 687-705, 2014.

Sutanudjaja, E. H., van Beek, L. P. H., Bosmans, J. H. C., Drost, N., de Graaf, I. E. M., de Jong, K., Peßenteiner, S., Straatsma, M. W., Wada, Y., Wanders, N., Wisser, D., and Bierkens, M. F. P.: PCR-GLOBWB 2.0: a 5 arc-minute global hydrological and water resources model, Geosci. Model Dev. Discuss., in preparation, 2015.

Van Beek, L. P. H.: Forcing PCR-GLOBWB with CRU data, [online] available at: http://vanbeek.geo.uu.nl/suppinfo/ vanbeek2008.pdf (last access: 2 June 2015), 2008.

Van Beek, L. P. H. and Bierkens, M. F. P.: The Global Hydrological Model PCR-GLOBWB: Conceptualization, Parameterization and Verification, [online] available at: http://vanbeek.geo.uu.nl/ suppinfo/vanbeekbierkens2009.pdf (last access: 2 June 2015), 2009.

Van Beek, L. P. H., Wada, Y., and Bierkens, M. F. P.: Global monthly water stress: 1 . Water balance and water availability, Water Resour. Res., 47, W07517, doi:10.1029/2010WR009791, 2011.

Wada, Y., Wisser, D., and Bierkens, M. F. P.: Global modeling of withdrawal, allocation and consumptive use of surface water and groundwater resources, Earth Syst. Dynam., 5, 15-40, doi:10.5194/esd-5-15-2014, 2014. 